\title{
Shall We Forget About L1 When Teaching English?
}

\section{Aynur Yürekli Kaynardağ}

\begin{abstract}
The use of students' mother tongue in foreign language classrooms has been an issue for many years; yet, without concrete agreement among teachers and scholars who are involved. Particularly, with the rise in communicative language teaching approaches, the tendency has moved towards monolingual teaching, by minimizing or banning the L1 completely. However, most of the time, the teaching and learning context, student profile and the tasks that the students are engaged in have been ignored, and decisions about monolingual and bilingual language teaching have been made. This paper briefly outlines six current studies investigating college students' use of L1 by making reference to the context and the task in which they are involved. After determining the functions of L1 use by students, the paper makes some suggestions about alternative ways to maximize target language use, especially in areas concerning within group communication, lack of language proficiency and classroom management procedures.
\end{abstract}

Key words: Mother Tongue, Language Acquisition, Monolingual, Bilingual.
$\ddot{O} z$

\section{İngilizce Öğretiminde Anadilimizi Unutmalı miy1z?}

Yillardır süregelen ve net bir sonuca bağlanamayan yabancı dil ögretiminde anadil kullanımının yeri, özellikle iletişimsel eğitim yaklaşımları ile birlikte daha da fazla sorgulanır hale gelmiştir. Ancak ögrenme ortami, yabancı dilin ikinci bir dil mi yabancı dil olarak mı ögretildiği veya öğrenme hedeflerinin eğitim ortamına göre nasıl değişiklik gösterdiği, sınıf içinde "tekdillilik" veya "ikidillilik" kararları verilirken göz ardı edilmiştir. Bu çalışma, yabancı dilöğrenme sürecindeöğrencilerinnezaman anadile başvurmalarının dil eğitimine katkısı olacağı, hangi durumlarda ise öğrenim sürecine ket vuracă̆ı ile ilgili bir alan taramasıdır. Öğrenme ortami, öğrenci grubu özellikleri ve araştırmada ele alınan ögrenme etkinliği baz alınarak analiz edilen altı çalışmanın bulguları sonucunda, ana dil kullanımının hangi durumlarda ve hangi iletişimsel işlevler doğrultusunda kullanıldiğı tespit edilmiştir. Belirlenen işlevler arasında öne çıkan grup-içi iletişim ihtiyaçları, dilbilgisel yetersizlikler ve sinıfyönetimi bazlı kullanımlar düşünülerek anadil kullanımını en aza indirgemek için uygulanabilecek önerilerde bulunulmuştur.

Anahtar kelimeler: Anadil, Dil Edinimi, Tekdillilik, İkidillilik.

* Yrd. Doç. Dr., İzmir Ekonomi Üniversitesi, Yabancı Diller Yüksekokulu. 


\section{Introduction}

One of the central discussions in the English Language Teaching (ELT) profession relates to the use of the mother tongue (L1) as part of classroom interaction or instruction. The history of methods and approaches shows that, in the past, L1 use was an important resource that both teachers and learners utilized when deemed necessary (see Grammar-Translation for details). However, with the increasing emphasis on 'communication', the use of L1 in the classroom has been deemphasized, and even banned.

It is a fact that first and second language acquisition, despite showing some similarities, are distinct in the sense that in the latter, there already is a functioning linguistic system in place, the system of L1. Yet, advocates of "English-only" tend to ignore this existence, along with all the cognitive processes that are involved. Naturally, learners refer to their L1 system to make some syntactic or semantic connections and to internalize new information from the target language. The fact that $\mathrm{L} 1$ is not evident in the classroom does not indicate that it is not processing in learners' minds. Thus, even though the teacher avoids using the mother tongue, and advises students against using it in class, the reality is that it continues functioning in the students' brains.

English is being taught by a wide variety of teacher types in various contexts for various purposes to learners with different backgrounds, which necessarily means that there are various ways and approaches to teaching. However, the trend in ELT is that methods and approaches that originated in the western world are directly taken and implemented outside its original context. Here, it is important to distinguish between English as a Second Language (ESL) and English as a Foreign Language (EFL). Many approaches, including the communicative approach, are designed for ESL contexts where learners have exposure to the target language outside the classroom as well, and their reason for learning covers needs such as survival or further education in the country in which the language is spoken. Therefore, to develop communicative skills is of vital importance, and learners are motivated to practice to the best of their ability, with minimal avoidance of the target language during class time. The EFL setting, however, represents a completely different teaching context, in which the exposure to the target language is limited to class time, lacking "authentic" communicative need for learners, and consequently, little motivation to make use of the class time for communicative purposes. Thus, the use of L1 in EFL classes emerges as a major issue for teachers and learners.

The literature on the use of L1 covers many different aspects. An important one is the students' and teachers' attitude to the use of L1 while learning a foreign language. The major tendency is that both have a more positive attitude towards the use of L1, especially if the aim is to make meaning clear or to handle classroom management procedures, including task instructions (McMillan and Rivers, 2011; Littlewood and Yu, 2011; Ford, 2009). 
Another study area is on the use of L1 by the teachers, mainly focusing on teachers' justifications for using the students' mother tongue to promote or facilitate learning and learning activities (de la Campa and Nassaji, 2009; Liu et al., 2004; Khati, 2011; Sali, 2014; Harbord, 1992). Here, the outstanding reasons centre around students' English proficiency level, which may lead teachers to use L1, thus save time by making the comprehension of certain aspects easier for students. However, it is also a fact that teachers use L1 to establish rapport; i.e. for social rather than academic functions.

Based on the literature regarding the use of L1 in language classrooms, studies yield mixed results, thus the issue is inconclusive. An important reason for this disagreement is that, when drawing conclusions and making generalisations, the local teaching and learning environment has not been sufficiently highlighted or taken into account as one of the main variables. A second criticism regards the purpose of the tasks analysed for L1 use, i.e. whether the tasks focus on content, communication, structure or vocabulary.

\subsection{The Teaching Context}

One major variable determining the context is the exposure that students have to the target language. In cases where English functions as a foreign language, there are scarce opportunities for using and developing the foreign language, mainly limited to the educational setting. Even within the educational setting, there are some issues regarding the use of the target language: a) it is usually bilingual, with students sharing the same L1, which gives them the opportunity and motivation to communicate in their mother tongue, rather than being constrained to use English as the main medium; b) even if the target language is used, it may not be very meaningful, and thus contribute to artificial language use. The combination of these two factors has an enormous impact on students' motivation to use, or to learn the target language. As such, language teaching approaches based on developing communicative competence and communicative coping strategies are less effective under EFL circumstances when compared to educational setting in ESL. Therefore, when making generalisations about the use of L1 and its effect on language learning or learners, the local context should be considered as one of the key factors.

\subsection{Task Aims}

During lessons, language teachers introduce a series of tasks, all of which have different purposes and objectives, ranging from awareness raising to production. When designing research about the use of $\mathrm{L} 1$, the purpose of the tasks should be relevant to the research objectives. Thus, a study done on vocabulary and L1 use could not be expected to shed light on a communicative pair work task and the effect of using L1. Therefore, before drawing 
conclusions about the use of L1, the task objectives should be clarified so as to allow teachers to make interpretations about the positive or negative impact of L1 use.

\subsection{Advantages of $\mathrm{L} 1$ Use}

A review of the literature on the positive effects of $\mathrm{L} 1$ use in foreign language classrooms reveals a number of benefits both for learners and teachers.

a) The use of L1 gives students an opportunity to approach classroom procedures with more confidence and understanding (Üstünel \& Seedhouse, 2005). When organizing tasks and giving instructions, particularly at lower levels of proficiency, teachers experience problems making procedures clear. In such cases, the use of L1 facilitates this process and prevents time-loss.

b) The use of L1 develops metalinguistic awareness with contrastive studies/tasks (Cenoz, 2007), especially, for grammatical structures and vocabulary, as relating new to existing knowledge provides a cognitive bridge. Learners are able to reduce the unfamiliarity of the target language item by relating it to the L1 system.

c) L1 use enriches the repertoire of language learning activities. That is, by using L1, teachers can set tasks which would otherwise be difficult to explain. Thus, even at lower proficiency levels, students are able to do more complex tasks when explained in the language they are confident. This plays a crucial role, especially, in explaining and organizing pair or group work.

d) The use of L1 is less time-consuming, both for the teacher and the student (Sampson, 2012). Learning a new language under classroom conditions means that both teachers and learners are given a limited time to perform certain learning activities; therefore, time should be used wisely. Excessive time should not be spent on trying to explain/demo/exemplify so that students understand a given lexical item or discover the function of a target structure. In such cases, the mother tongue allows teachers to use time more effectively for language practice activities.

e) The use of L1 helps prevent ambiguity, student reiterate to ensure full understanding (Sampson, 2012). The English explanation of a word in English might confuse learners about its meaning, and create uncertainty. Once they know exactly what it means in their own language, they can make the semantic connections.

f) The use of L1 encourages and promotes socializing by making it easier to establish group solidarity (Sampson, 2012). As almost all students share the same mother tongue, it is easier for students to socialize in their own language. Especially, in tasks that require team work, students feel the need to establish a feeling of belonging, which is much more difficult in the target language. Thus, the use of L1 can be said to fulfill a social function. 
g) The use of L1 helps to maintain fluency, especially in written and oral communicative tasks. If a student does not know the English word for what he intends to express, two choices are available; either giving up, leading to a communication breakdown, or continuing by replacing the unknown word with its equivalent in L1. So, in terms of fluency, the use of L1 can serve as a repair strategy for effective communication.

\subsection{Disadvantages of $\mathrm{L} 1$ use}

a) L1 use limits the exposure to L2. There are strong arguments in favour of a complete L1 ban, suggesting that high exposure to L 2 will maximize learning (Elridge, 1996). Especially in EFL settings, target language exposure is limited to the classroom environment, and the use of L1 deprives students of their right to interact with and communicate in the target language, an opportunity not available in their everyday environment.

b) There is a wide range of teaching materials available for English-only environments (Macaro, 2005), and this, inevitably, enriches the material and tools for teaching. It lessens the burden of preparing home-made teaching material, which are often compiled or developed by non-experts, and which are never piloted.

c) Using $\mathrm{L} 1$ or allowing the use of $\mathrm{L} 1$ conflicts with the belief that communication develops through predominantly communicating in the target language (Carless, 2007). If the primary concern is the development of communicative skills, then the only way to achieve this aim is to create opportunities to practice the skills in the target language, rather than allowing code-switching when deemed necessary.

d) Encouraging the use of L2 motivates students (Levine, 2003) by giving a feeling of accomplishment. Students who see that they can express themselves in the target language gain confidence and transfer their communication skills to other tasks and situations.

e) The use of $\mathrm{L} 1$ creates the risk of overuse. Once the use of $\mathrm{L} 1$ is made available to students, they might resort to that resource even when unnecessary. Thus, the ultimate aim and objective, which is learning and using the target language, is distorted or deviated from.

This aim of this paper is neither to encourage the use of L1 in language classes, nor to support an 'English-only' perspective. Rather it aims at highlighting the importance of the local context and the objectives of specific tasks when adapting a teaching approach by focusing on the so-called 'communicative classroom' in an EFL setting. The main issues to be addressed are as follows:

a) What is the importance of tasks in L1 use?

b) How can the use of L1 be minimized? 


\section{Method}

After a thorough review of the recent literature on the use of $L 1$, research from selected studies were analysed in terms of their context and the tasks that were the basis for data collection. Then, possible solutions are offered to minimize the use of L1- while acknowledging its advantages- towards the aim of implementing a communicative approach to ELT in an EFL environment.

Studies selected for the analysis were based on three main criteria: a) college/university setting, b) task objective, c) L1 use and functions. Therefore, studies that share similar contexts were included in the analysis to allow valid generalisations to be made. Thus, all studies reported on were conducted in a bilingual college/university EFL classroom setting, i.e. studies that focused specifically on students' L1 use in an EFL. Studies that did not fulfil this purpose, i.e. based on attitudes to the use of L1, or the use of L1 by teachers, were excluded. Only six recent studies meeting all three criteria could be found.

\section{Results}

The results of the studies are outlined in Table 1.

Table 1 Overview of Studies in Students' L1 Use

\begin{tabular}{|c|c|c|}
\hline \multirow{4}{*}{ Leeming (2011) } & Participants & Japanese high school students \\
\hline & Task Type & Pair-work/jigsaw picture telling \\
\hline & L1 use & high \\
\hline & Functions of L1 & $\begin{array}{l}\text { Intra-psychological speech } \\
\text { Task control } \\
\text { Social purposes }\end{array}$ \\
\hline \multirow[b]{4}{*}{ Sampson (2011) } & Participants & Spanish adult learners \\
\hline & Task Type & Pair-work/whole class-form focused \\
\hline & L1 use & high \\
\hline & Functions of L1 & $\begin{array}{l}\text { For vocabulary equivalence } \\
\text { Task control } \\
\text { Floor holding } \\
\text { Social purposes } \\
\text { Avoidance }\end{array}$ \\
\hline \multirow[t]{4}{*}{$\begin{array}{l}\text { Latsany- phone \& } \\
\text { Bouan-geune (2009) }\end{array}$} & Participants & Laos university students \\
\hline & Task Type & Vocabulary teaching \\
\hline & L1 use & high \\
\hline & Functions of L1 & Meaning clarification through direct translation \\
\hline
\end{tabular}




\begin{tabular}{|c|c|c|}
\hline \multirow[b]{4}{*}{ Wang \& Wen (2002) } & Participants & Chinese University students \\
\hline & Task Type & Narrative $\&$ argumentative writing task \\
\hline & L1 use & high \\
\hline & Functions of L1 & $\begin{array}{l}\text { Text generation } \\
\text { Idea generation } \\
\text { Idea organizing } \\
\text { Task control }\end{array}$ \\
\hline \multirow[b]{4}{*}{ Weijena et. al. (2009) } & Participants & Dutch University students \\
\hline & Task Type & Essay writing \\
\hline & L1 use & moderate \\
\hline & Functions of L1 & $\begin{array}{l}\text { Self-instruction } \\
\text { Structuring } \\
\text { Goal setting } \\
\text { Generating ideas }\end{array}$ \\
\hline \multirow{4}{*}{ Greggio \& Gil (2007) } & Participants & Brazilian University students \\
\hline & Task Type & Form-focused general instruction \\
\hline & L1 use & high \\
\hline & Functions of L1 & $\begin{array}{l}\text { Grammar explanations } \\
\text { Correction activities }\end{array}$ \\
\hline
\end{tabular}

The literature on the use of L1 shows that there is a need for greater coherence in studies regarding the use of $L 1$, taking multiple perspectives. A review of six selected studies shows that a) there is a limited number of studies dealing with the use of L1 by the students under EFL conditions; b) each study focuses on a different aspect of the classroom task, which inevitably creates discrepancies in the amount and purpose of students' L1 use; c) methodologically, some studies use recording and analysing classroom discourse to determine the functions of L1 use, whereas others rely on self-report. Despite different approaches, all six studies report the use of L1 by students as 'excessive' or 'high'. However, before describing L1 use as excessive, there needs to be a consideration of the requirements and focus of the tasks or learning activities.

\section{Discussion and Suggestions}

For many years, especially after the introduction of the Communicative Language Teaching approach into EFL contexts, teachers' and students' use of L1, has been considered as a hindrance to language learning, as it is claimed that it would be counterproductive as it minimizes the exposure to English. Furthermore, it takes away opportunities for communicating and practice the target language. In many cases, this trend has led to 'banning' the L1 completely, with the intention of reinforcing the use of L2, which is quite limited in EFL settings. However, in this process, there has been no serious analysis of 
needs regarding different tasks and activities carried out during a language class. As it can be seen, the six studies reported above consider different classroom tasks, each of which pose different cognitive challenges, requiring different skills and strategies. Therefore, in the light of the literature on L1 use, I suggest that rather than simply forbidding a system that already exists in the students' repertoire, it should be exploited to the benefit of language learning. Yet, I do believe that its use should be minimized, and it should not have a detrimental effect on the objective of the learning task being carried out.

In cases where the objective of the task requires students to produce the target language in a communicative context, such as pair or group work activities, allowing L1 use would certainly help in achieving outcomes but would prevent the development of communicative skills and strategies. Thus, the use of L1 would have a harmful effect on their language development.

On the other hand, if students encounter difficulties understanding how a particular task needs to be done, i.e. a completely procedural and non-academic problem-they should have the right to use their $\mathrm{L} 1$ resources to be able to proceed.

Having said this, sometimes it can be quite challenging for the teacher to deter students from using the L1, due to the ease and convenience of code-switching to a common language. So, the question is: to what extent, when, and how could we make use of L1 in class without causing harm in terms of the development of communicative skills? The word 'communication' plays a key role here.

As the studies mentioned above also suggest, focus on form and focus on communication are the main considerations. The use of $\mathrm{L} 1$ is more evident when focusing on form, lexis or structure, both by the teacher and the students. There are several reasons for this, one of which is to ensure that the concept is understood correctly. In other words, learners refer to L1 to ensure and check their own comprehension, which has a value in language learning.

However, in a group work, where students are expected to reach a decision about a given topic, and present it to the class, using English for the final presentation alone and doing the whole discussion in the mother tongue, certainly has a negative impact on achieving the main objective of the task, i.e. practicing the target language during the discussions. There, the use of $\mathrm{L} 1$ for purposes other than maintaining fluency, certainly poses a barrier to the successful implementation of the task.

The general view, today, suggests that there is room for L1, if carefully exploited and not overused. However, I believe that we, as teachers of English, have the responsibility to maximize students' opportunities to practice the target language, and minimize the unnecessary and unplanned use of the mother tongue. The following recommendations could serve as a guide to the effective balance of L1 and L2 use in bilingual language classes.

Finding alternative approaches to code-switching is one way to minimize students' use of L1. After carefully identifying the reasons and occasions in which L1 is dominant, students 
can be trained in strategies that would enable them to achieve the same function without the use of L1, and thus, develop confidence. For example, if students choose to use the L1 equivalent of a word despite knowing the L 2 word, then to use fillers can help them gain thinking time for recall.

One fundamental function of L1 use of students seems to be task control and continuity. Thus, when setting up tasks, it is recommended that teachers ensure that students are prepared for the task, both lexically and structurally, in order to minimize the use of L1. If students are free from pressure of lack of L2, they would be more enthusiastic and motivated to experiment with the target language. Equipping the students with necessary linguistic tools prior to the task might, therefore, increase students' chances of successfully completing the task without reference to $\mathrm{L} 1$.

One of the major findings of previous studies regards the social function of L1; i.e. establishing rapport with peers and using L1 for socializing purposes. Pre-teaching the language for socializing, or limiting the use of L1 for that particular function only, would eventually lead to greater L2 use. When facing a 'ban', students are more likely to resist. However, by explaining that L1 is not banned, but that its use is restricted to specific moments or functions only, resistance to the use of L 2 would be lowered.

\section{Conclusion}

The aim of teaching a foreign language and under which context the teaching takes place, play a critical role when drawing conclusions about the use of L1. A general guide should be the task objective and the specific learning context. As a general objective, it is important that students have as much exposure as possible to the target language and the use of the mother tongue should be limited to justifiable situations. However, we should not forget that students have constant access to their L1, and cognitively, it is in process throughout the language learning task, whether banned or not. As a result, provided that the use of L1 supports the acquisition of the target language, and provided that it is not overused and turned into the medium of instruction, there is a clear value in facilitating cognitive connections between the known and the unknown, the mother tongue and the target language.

\section{Bibliography}

Carless, D. (2007). Student use of the mother tongue in the task-based classroom. ELT Journal 62 (4), 331-338.

Cenoz, J. (2007). The acquisition of pragmatic competence and multilingualism in foreign language 
contexts. In E.Alco'n Soler and M. P. Safont Jorda' (eds.), Intercultural language use and language learning. Dordrecht: Springer.

De la Campa, J., Nassaji, H. (2009). The amount, purpose and reasons for using L1 in L2 classrooms. Foreign Language Annals 42 (4), 742-759.

Eldridge, J. (1996). Code-switching in a Turkish secondary school. ELT Journal 50 (4), 303-11.

Ford, K. (2009). Principles and practices of L1/L2 use in the Japanese university EFL classroom. JALT Journal 31( 1), 63-80.

Greggio, S., and Gil, G. (2007). Teacher's and learners' use of code switching in the English as a foreign language classroom: a qualitative study. Linguagem \& Ensino 10 (2), 371-393.

Harbord, J. (1992). The use of the mother tongue in the classroom, ELT Journal 46 (4), 350-355.

Khati, A. R. (2011). When and why of mother tongue use in English classrooms. Journal of NELTA $16(1-2), 42-51$.

Latsanyphone, S. and Bouangeune, S. (2009) . Using L1 in teaching vocabulary to low English proficiency level students: A case study at the University of Laos. English Language Teaching Journal, 2 (3), 186-193.

Leeming, P. (2011). Japanese high school students' use of L1 during pair-work. International Journal of Applied Linguistics 21 (3), 360-382.

Levine, G. 2003. Student and instructor beliefs and attitudes about target language use, first language use, and anxiety: report of a questionnaire study. The Modern Language Journal 87(3), 343-64.

Littlewood, W. and Yu, B. (2011). First language and target language in the foreign language classroom. Language Teaching 44 (1), 64-77.

Liu, D., Ahn, G. S., Baek, K. S. and Han, N.O. (2004). South Korean high school English teachers' code switching: Questions and challenges in the drive for maximal use of English in teaching. TESOL Quarterly 38 (4), 605-638.

Macaro, E. (2005). Code switching in the L2 classroom: a communication and learning strategy. In E. Llurda (ed.), Non-native language teachers: Perceptions, challenges and contributions to the profession. New York: NY Springer.

McMillan, B. and Rivers, D. (2011). The practice of policy: Teacher attitudes toward "English only”. System 39, 251-263.

Sali, P. (2014). An analysis of the teachers' use of L1 in Turkish EFL classrooms. System 42, 308-318.

Üstünel, E. and P. Seedhouse. (2005). Why that, in that language, right now? Code-switching and pedagogical focus. International Journal of Applied Linguistics, 15(3), 302-325.

Wang, W. and Wen, Q. (2002). L1 use in the L2 composing process: An exploratory study of 16 Chinese EFL writers. Journal of Second Language Writing 11(3), 225-246.

Weijena, D., Bergha, H., Rijlaarsdamb, G. and Sandersa, T. (2009). L1 use during L2 writing: An empirical study of a complex phenomenon. Journal of Second Language Writing Volume 18(4), 235-250.

Sampson, A. (2012). Learner code-switching versus English only. ELT Journal Volume 66(3), 293-303. 